\title{
Immune opsonins modulate BLyS/BAFF release in a receptor- specific fashion*
}

\author{
Xinrui $\mathrm{Li}^{\dagger}, \neq$ Kaihong Su${ }^{\dagger}$, Chuanyi $\mathrm{Ji}^{\dagger}$, Alexander J. Szalai ${ }^{\dagger}$, Jianming $\mathrm{Wu}^{\dagger}$, Yan Zhang ${ }^{\dagger}$, \\ Tong Zhou ${ }^{\dagger}$, Robert P. Kimberly ${ }^{\dagger, \ddagger, \S}$, and Jeffrey C. Edberg ${ }^{\dagger, \S, \uparrow}$ \\ tDivision of Clinical Immunology and Rheumatology, Department of Medicine, University of \\ Alabama at Birmingham, Birmingham, AL \\ FDepartment of Cell Biology, University of Alabama at Birmingham, Birmingham, AL \\ $\S$ Department of Microbiology, University of Alabama at Birmingham, Birmingham, AL
}

\begin{abstract}
TNF ligand superfamily member 13B (B-lymphocyte stimulator (BLyS), B cell activating factor (BAFF)) promotes primary B cell proliferation and immunoglobulin production. While the soluble form of BLyS/BAFF is thought to be the primary biologically active form, little is known about the regulation of its cleavage and processing. We provide evidence that $\mathrm{Fc} \gamma$ receptor cross-linking triggers a rapid release of soluble, biologically active BLyS/BAFF from myeloid cells.

Surprisingly, this function is primarily mediated by Fc $\gamma \mathrm{RI}$, but not Fc $\gamma$ RIIa as defined by specific $\mathrm{mAb}$, and can be initiated by both IgG and $\mathrm{C}$ reactive protein (CRP) as ligands. The generation of a $\mathrm{B}$ cell proliferation and survival factor by both innate and adaptive immune opsonins through engagement of an $\mathrm{Fc} \gamma$ receptor, which can also enhance antigen uptake and presentation, provides a unique opportunity to facilitate antibody production. These results provide a mechanism by which $\mathrm{Fc} \gamma$ receptors can elevate circulating BLyS levels and promote autoantibody production in immune complex mediated autoimmune diseases.
\end{abstract}

\section{Key Works}

Fc Receptors; Monocytes/Macrophages; Human; Autoimmunity

\section{Introduction}

B lymphocyte stimulator (BLyS), also known as BAFF (B cell-activating factor of the TNF family)/TNFSF13B, TALL-1/zTNF4/THANK, is an important member of the tumor necrosis factor (TNF) ligand superfamily (reviewed in (1-4)). BLyS/BAFF regulates B cell proliferation and differentiation and regulates immunoglobulin production (5). In facilitating B cell maturation, BLyS/BAFF preferentially supports T2 cell survival compared to T1-T2 differentiation $(6,7)$.

Studies in both model systems and humans have suggested that BLyS/BAFF is involved in humoral immune responses and in the pathogenesis of autoantibody mediated autoimmune diseases. BLyS ${ }^{-/}$mice show deficiencies in peripheral B cell development and maturation (8-10). Additionally, overproduction of BLyS/BAFF in transgenic mice leads to increased

\footnotetext{
* This work was supported by grants from the National Institutes of Health (AR42476, AR33062 and P01-AR49084 and MO1RR00032).

ॠAddress correspondence to Dr. Jeffrey C. Edberg, University of Alabama at Birmingham, 1825 Univ Blvd Rm 207 Shelby, Birmingham, AL 35294, 205-934-0894, jedberg@uab.edu.
} 
germinal center formation, high levels of autoantibody production (rheumatoid factor, antiDNA) and immunoglobulin deposition in the kidney (11). Similar to observations of increased BLyS in autoimmune mice, elevations in circulating BLyS/BAFF are found in the serum of patients with a variety of autoimmune diseases including SLE, RA, Sjögrens Syndrome and WG (12-14).

BLyS/BAFF is expressed in cells of both hematopoietic and non-hematopoietic origins. Hematopoietic cells expressing BLyS/BAFF include monocytes/macrophages, some lymphocytes and dendritic cells. In these cells, BLyS/BAFF is initially expressed as a cell bound transmembrane protein that is cleaved upon cell activation and is typically found in soluble form as a BLyS/BAFF trimer. In the presence of soluble APRIL (a proliferationinducing ligand), a trimer of BLyS/APRIL has also been demonstrated (15). Neutrophils express BLyS/BAFF, but unlike other myeloid and lymphoid cells, BLyS/BAFF is cleaved intracellularly into its truncated, soluble form (16). Non-hematopoietic cells such as astrocytes and fibroblast-like synoviocytes have been shown to express BLyS/BAFF (1719). While the regulation of expression of BLyS/BAFF is not completely understood, both IFN $\gamma$ and G-CSF upregulate total BLyS/BAFF protein in monocytes and neutrophils (20), and treatment of monocytes with LPS also induces an increase in soluble BLyS/BAFF levels in culture $(15,20)$.

Although the membrane associated form of BLyS/BAFF has potential for biological effects, the soluble form of BLyS/BAFF appears to be the primary biologically active form (21). We demonstrate rapid receptor-specific induced release of soluble biologically active BLyS/ BAFF from myeloid cells. Surprisingly, this release is triggered primarily by crosslinking Fc $\gamma$ RI with $\mathrm{C}$ reactive protein (CRP) or IgG, opsonins of the innate and adaptive immune systems. $\mathrm{Fc} \gamma$ receptor ligation, especially that of $\mathrm{Fc} \gamma \mathrm{RI}$, is known to enhance antigen uptake and presentation $(22,23)$. Thus the concomitant elaboration of a factor promoting B cell survival and Ig production in response to either IgG or CRP presumably provides a microenvironment that facilitates the humoral immune response. Furthermore, these observations suggest a potentially important link between innate and adaptive immune responses and between elevations in circulating BLyS/BAFF and immune complex mediated autoimmune disease.

\section{Materials and Methods}

\section{Isolation of peripheral blood mononuclear cells (PBMCs) and B cells}

Blood from healthy donors was collected into heparinized tubes (Becton Dickinson, Franklin Lakes, NJ). PBMCs were isolated by Ficoll-Hypaque gradient centrifugation as previously described (24). CD19+ cell were purified using Magnetic Micro Beads (Miltenyi Biotec, Auburn, CA) on positive-selection columns. All studies were approved by the Institutional Review Board for Human Use.

\section{Cell cultures}

Human U937, THP-1, and HL-60 cell lines were maintained as suspension culture in RPMI 1640 (Invitrogen Life Technologies, Carlsbad, CA) medium supplemented with 10\% fetal calf serum, $1 \mathrm{mM}$ sodium pyruvate, penicillin $(100 \mathrm{U} / \mathrm{ml})$, and streptomycin $(100 \mu \mathrm{g} / \mathrm{ml})$. 293T cells were stably transfected with a cDNA-encoding BLyS and were maintained as adherent cultures in DMEM (Invitrogen Life Technologies, Carlsbad, CA) medium with $10 \%$ FBS and $0.5 \mathrm{mg} / \mathrm{ml} \mathrm{G} 418$. 


\section{Antibodies and Reagents}

Hybridoma clones producing monoclonal anti- BLyS antibodies were generated by immunizing BALB/c mice with $200 \mu \mathrm{g}$ recombinant human BLyS (extracellular domain, aa 71 to aa 285) before fusion of lymph node cells with NS1 myeloma cells. The primary hybridoma clones were screened by ELISA for binding to the recombinant BLyS. Positive clones were further screened with the transfected 293T cells expressing the membrane form of human BLyS. Cell surface expression of human BLyS was confirmed by flow cytometry using TACI-Fc fusion protein $(10 \mu \mathrm{g} / \mathrm{ml})$ followed by incubation with PE-conjugated goatanti-human IgG (Southern Biotech) (25). The monoclonal anti-BLyS antibody (mAb 7D4) was chosen for flow cytometry and immunoprecipitation.

A blotting polyclonal anti-BLyS antibody (pAb) was obtained from Alexis Biochemicals, San Diego. Monoclonal anti-CRP antibody HD2-4 (26) and anti-Fc $\gamma$ RIIb mAb 4F5 (27) were used as described. Anti-Fc $\gamma \mathrm{RI}$ mAb 32.2 and anti-Fc $\gamma$ RII mAb IV.3 hybridoma cell lines were purchased from American Type Culture Collection (Manassas, VA). Anti-CD14 and anti-CD19 antibodies were purchased from Caltag Laboratories, $\mathrm{CA}$. MAb Fab/F(ab' ${ }_{2}$ fragments were prepared by Rockland Immunochemicals and were free of detectable Fc region as assessed by blotting. $\mathrm{F}\left(\mathrm{ab}^{\prime}\right)_{2}$ goat anti-mouse $\mathrm{IgG}(\mathrm{GaM})$ was obtained from Jackson ImmunoResearch Laboratories (West Grove, PA). Rabbit IgG, human IgG isotype controls, IFN $\gamma$, and human CRP were from Sigma. Aggregated human IgG was prepared by heating $20 \mathrm{mg} / \mathrm{ml}$ human IgG for 30 minutes at $55^{\circ} \mathrm{C}$ followed by removal of insoluble aggregates by spinning at $2000 \mathrm{xg}$ for 10 minutes. In addition, highly purified CRP (sodium azide free, low endotoxin) was prepared from donor sera using a standard affinity chromatography protocol (28). Recombinant BAFF-R was purchased from BioVision, Inc (Mountain View, CA), and was labeled by using Alexa Fluor 488 Microscale Protein Labeling Kit from Molecular Probes.

\section{Detection and quantification of BLyS}

Soluble BLyS levels were assayed in supernatants of U937 or THP-1 cells by immunoprecipitation and Western blot. Cell associated BLyS was assessed by blotting whole cell lysates (WCL) or by immunoprecipitation. Cells were lysed at $5 \times 10^{7} \mathrm{cells} / \mathrm{ml}$ in PBS/1\% NP-40 lysis buffer containing a protease inhibitor cocktail (Roche Diagnostics, IN). Lysates or culture supernatants were then preincubated with protein G-Agarose beads at $4^{\circ} \mathrm{C}$ for $1 \mathrm{~h}$ followed by incubation with 7D4-conjugated protein G-agarose beads (Roche Diagnostics, IN) at $4^{\circ} \mathrm{C}$ overnight. After 3 washes with PBS containing $0.1 \%$ Tween 20, the beads were boiled in SDS loading buffer. The samples were separated by SDS-PAGE and transferred onto nitrocellulose membranes. After blocking with 5\% nonfat dry milk, blots were probed with anti-BLyS pAb followed by HRP-conjugated mouse anti-rabbit IgG and detected with $\mathrm{ECL}^{\mathrm{TM}}$ Western Blotting Detection Reagents (GE Healthcare).

\section{Analysis of Intracellular $\mathrm{Ca}^{2+}$ Concentrations}

Calcium influx was measured as previous described (29). Briefly, U937 cells were incubated at $37^{\circ} \mathrm{C}$ for 40 min with $5 \mu \mathrm{M}$ Indo-1/AM (Molecular Probes, Eugene, OR). After loading, the cells were washed once with modified HBSS $\left(1.1 \mathrm{mM} \mathrm{CaCl}_{2}, 1.6 \mathrm{mM} \mathrm{MgCl}_{2}\right.$ and $1 \mathrm{mg}$ / $\mathrm{mL} \mathrm{BSA}, \mathrm{pH} 7.3$ ) and incubated with different anti-Fc $\gamma \mathrm{R} \mathrm{mAbs}$ for $30 \mathrm{~min}$ at $4^{\circ} \mathrm{C}$ followed by one cold wash. The cells were then resuspended to $5 \times 10^{6} / \mathrm{ml}$ and analyzed on an SLM 8000C Spectrofluorometer (SLM-Aminco, Urbana, IL). Cells were stimulated with goat anti-mouse $\mathrm{F}\left(\mathrm{ab}^{\prime}\right)_{2}$ at 60 seconds. 


\section{Specific FcyR Cross-linking}

U937 cells or human PBMC were first incubated with anti-Fc $\gamma$ RI IgG or $\mathrm{F}\left(\mathrm{ab}^{\prime}\right)_{2}(\mathrm{mAb}$ 32.2), with anti-Fc $\gamma$ RIIa IgG or Fab (mAb IV.3), and/or with anti-Fc $\gamma$ RIIb IgG or F(ab' $\left.{ }^{\prime}\right)_{2}$ $(\mathrm{mAb} 4 \mathrm{~F} 5)$ at saturating concentrations $(10 \mu \mathrm{g} / \mathrm{ml})$ for $30 \mathrm{~min}$ at $4^{\circ} \mathrm{C}$, washed twice, and resuspended in modified HBSS followed by cross-linking with $\mathrm{GaM} \mathrm{F}\left(\mathrm{ab}^{\prime}\right)_{2}(35 \mu \mathrm{g} / \mathrm{ml})$ at $37^{\circ} \mathrm{C}$ for $15 \mathrm{~min}$. Cells were then washed and the remaining $\mathrm{GaM}$ binding sites were blocked with mouse IgG1/IgG2b mixture (final concentration $10 \mu \mathrm{g} / \mathrm{ml}$ ) before FACS analysis.

\section{Flow cytometry}

Cells were prepared for flow cytometric analysis by incubating cells with saturating concentrations of specific $\mathrm{mAb}$ or an isotype control for $30 \mathrm{~min}$ on ice, followed by incubation with goat anti-mouse $\mathrm{F}\left(\mathrm{ab}^{\prime}\right)_{2}$ conjugated with FITC for $30 \mathrm{~min}$ on ice. Alternatively, cells were stained with biotinylated 7D4 followed by FITC-conjugated streptavidin. In isolated PBMC, monocytes were identified with anti-CD14 and B cells were identified with anti-CD19. Cells were analyzed on a FACSCan flow cytometer and data were analyzed using Cell Quest software (Becton Dickinson Immunocytometry, CA).

\section{B cell viability assay}

Survival of CD19+ B cells was assessed as previously described (20). Briefly, B cells at a density of $1 \times 10^{6} / \mathrm{ml}$ were seeded in the upper chamber of transwell (Corning Coster, NY) in RPMI-1640 medium supplemented with $10 \%$ fetal bovine serum. Medium, or $5 \times 10^{6} / \mathrm{ml}$ CD19-depleted mononuclear cells (MNC), or $1 \times 10^{6} / \mathrm{ml}$ U937 cells were placed in the lower chambers with or without IgG pre-coating. After seeding, the cells were cultured for 3 days. Surviving B cells were quantified by light microscope in the presence of trypan-blue.

\section{Data analysis and statistics}

Results are presented as mean \pm SEM, and differences between means were analyzed using the Student's t test (GraphPad Prism). A probability of 0.05 was used to reject the null hypothesis that there is no difference between the experimental and control groups.

\section{Results}

\section{CRP induces decrease of membrane BLyS/BAFF expression on U937 cells}

To examine the regulation of cell surface BLyS expression, we prepared and characterized a monoclonal anti-BlyS antibody (clone: 7D4, IgG2b, $\kappa$ ) that was selected based on its ability to recognize both the soluble and the membrane forms of BLyS. Activity of mAb 7D4 was determined using $293 \mathrm{~T}$ cells transfected with full length human BLyS (Fig. 1 $A$, upper panel). TACI-Fc fusion protein was used as a positive control for detection of membrane BLyS expression (Fig. 1 $A$, lower panel). No binding of mAb 7D4 to the empty vector transfected control 293T cells was observed. Detection of soluble BLyS was performed using a previously established BLyS ELISA with mAb 7D4 as the capture antibody (12). Soluble BLyS was detected in the supernatant of cells transfected with BLyS, but no soluble BLyS was detected in culture supernatants of cells transfected with empty vector (Fig. $1 B$ ). Immunoprecipitation of supernatant derived BLyS with mAb 7D4 followed by Western blot confirmed that the released BLyS from the transfected cells was the predicted 17kd cleaved form of BLyS, and BLyS in transfected 293T cell lysates was the full length 34kd form (data not shown). These results indicate that mAb 7D4 is able to bind both cell surface and released soluble BLyS. 
Circulating monocytes and monocytic cell lines constitutively express BLyS/BAFF on the cell surface and as previously reported we found that stimulation of these cells with IFN $\gamma$ induced a marked increase in the level of surface BLyS expression (Fig. 2). Because CRP, an acute phase reactant and opsonin of the innate immune system, may be an important modulator of acquired immune responses, we determined whether CRP could alter cell surface BLyS/BAFF expression. Indeed, membrane BLyS/BAFF expression on both constitutive and IFN $\gamma$ stimulated human monocytic cell line U937 is decreased by crosslinking of CRP with $\mathrm{F}\left(\mathrm{ab}^{\prime}\right)_{2}$ fragments of a monoclonal anti-CRP antibody HD2-4. In cells with constitutive BLyS expression, cross-linked CRP induced a $16.2 \pm 5.8 \%$ decrease $(\mathrm{p}=0.026, \mathrm{n}=8)($ Fig. $2 A)$ and in IFN $\gamma$ stimulated cells cross-linked CPR induced a $23.1 \pm 5.6 \%$ decrease in surface BLyS expression $(\mathrm{p}=0.014, \mathrm{n}=5)($ Fig. $2 B)$.

\section{FcyR cross-linking causes reduced membrane BLyS/BAFF expression}

CRP can exert biological effects on myeloid cells through engagement of $\mathrm{Fc} \gamma$ receptors as cognate receptors (30). To directly determine if the decrease in BLyS/BAFF surface expression can be modulated by Fc $\gamma$ receptors, we incubated U937 cells with plate bound IgG. In contrast to the induction of surface BLyS expression by IFN $\gamma$, overnight culture of U937 on IgG coated wells resulted in a marked decrease in cell surface BLyS/BAFF expression $(52.2 \pm 3.0 \%, \mathrm{p}=0.003, \mathrm{n}=3$ )(Fig. $2 C$ ). In addition to surface bound $\mathrm{IgG}$, soluble aggregated human IgG also resulted in a marked decrease in cell surface BLyS/BAFF expression (Fig. 2D) demonstrating that adherence to a surface is not necessary for the IgGinduced decrease in surface BLyS expression. To confirm that the Fc portion of the antiBLyS antibody 7D4 was not contributing to the apparent IgG-induced decrease in cell surface BLyS, we utilized a soluble recombinant BLyS receptor (TNFSF13C or BAFF-R) corresponding to the extracellular domain for detection of surface BLyS. Indeed, using the soluble BAFF-R we observed the same IgG induced decrease in surface BLyS expression after IgG stimulation $(54.7 \%+5.8 \%, \mathrm{p}=0.016, \mathrm{n}=4)($ Fig. $2 E)$. Comparable results with surface bound $\operatorname{IgG}$ were observed in two other human monocytic cell lines, THP-1 and HL-60 (data not shown). Overnight culture of U937 cells on mouse IgG F( $\left.\mathrm{ab}^{\prime}\right)_{2}$ coated wells did not change BLyS/BAFF expression (data not shown).

To examine whether the effect of Fc $\gamma \mathrm{R}$ cross-linking on monocytic cell lines could be extended to primary human cells, peripheral blood mononuclear cells were isolated and stimulated with aggregated human IgG, and surface BLyS/BAFF expression on CD14+ monocytes was measured by flow cytometry. In concert with the cell line data, monocyte cell surface BLyS was consistently decreased by Fc $\gamma \mathrm{R}$ engagement (Fig. $2 F$ ). These results indicate that $\mathrm{Fc} \gamma \mathrm{R}$ stimulation of both monocytes and monocytic cell lines induces a marked decrease in cell surface BLyS/BAFF.

\section{Kinetic Analysis of membrane BLyS/BAFF expression}

The kinetics of loss of cell surface BLyS were determined (Fig. 3). In contrast to the transcriptional regulation of BLyS expression by IFN $\gamma$ which peaks at 24 hours (Fig. $3 A$ ) $(15,31), F c \gamma R$ cross-linking resulted in a rapid loss of cell surface BLyS/BAFF from the surface of U937 cells. Indeed, stimulation with surface IgG resulted in the rapid down regulation of membrane BLyS/BAFF expression within 5 min, reaching a maximum by 15 $\min ($ Fig $3 B$ ). The decreased levels of cell surface BLyS/BAFF did not rebound during continued exposure to surface IgG over a period of $48 \mathrm{hrs}$ (Fig. $3 A$ ). We did not detect any change in BLyS mRNA levels by quantitative PCR during the 8-24hr incubation with $\operatorname{IgG}$ (results not shown). These results, together with the kinetic pattern of BLyS/BAFF loss from the cell surface, rule out the possibility that the Fc $\gamma \mathrm{R}$ induced change on BLyS/BAFF expression is transcriptional. 


\section{Increased soluble BLyS/BAFF is released into supernatants upon FcyR aggregation}

To determine the mechanism of loss of cell surface BLyS/BAFF, we considered the possibility that membrane BLyS/BAFF was released from the cell surface upon cleavage. Accordingly, we immunoprecipitated soluble BLyS from cell free supernatants collected after Fc $\gamma$ R ligation. Both THP-1 cells (Fig. 4A) and U937 cells (Fig. 4B) constitutively express the $32 \mathrm{kD}$ membrane BLyS as seen by immunoprecipitation from cell lysates. In contrast, only the $17 \mathrm{kD}$ soluble form could be immunoprecipitated from the cell-free culture supernatants after overnight IgG stimulation, demonstrating the appearance of a cleaved form of soluble BLyS/BAFF. The kinetics of the appearance of detectable cleaved soluble BLyS/BAFF demonstrated increasing protein at $8 \mathrm{hrs}$ and $20 \mathrm{hrs}$ after stimulation (Fig. 4B). A low level of cleaved BLyS/BAFF protein was observed in the non-stimulated cells after overnight culture consistent with a low level of constitutive BLyS/BAFF shedding. While we cannot formally exclude the possibility that some cell surface BLyS/BAFF is also internalized after $\mathrm{Fc} \gamma \mathrm{R}$ cross-linking, these results clearly show the $\mathrm{Fc} \gamma \mathrm{R}$ activation results in the generation of cleaved soluble BLyS/BAFF.

\section{FcyRI (CD64) is the major inducer of BLyS/BAFF release}

Among different families of $\mathrm{Fc} \gamma \mathrm{Rs}$, two activating receptors Fc $\gamma \mathrm{RI}$, Fc $\gamma \mathrm{RIIa}$ and the inhibitory Fc $\gamma$ RIIb, are expressed on the surface of U937 cells, THP-1 cells and circulating monocytes. To determine which of those Fc $\gamma$ Rs is responsible for BLyS/BAFF release, receptor-specific activation of cells with specific anti-receptor mAbs was performed. To our surprise, using U937 cells, cross-linking of Fc $\gamma \mathrm{RI}$ but not Fc $\gamma$ RIIa induced loss of BLyS/ BAFF expression. Fc $\gamma$ RI (CD64) cross-linking with mAb $32.2 \mathrm{IgG}$ or $\mathrm{F}\left(\mathrm{ab}^{\prime}\right)_{2}$ resulted in a rapid and significant loss of surface BLyS/BAFF expression while cross-linking of Fc $\gamma$ RIIa (CD32A) with mAb IV.3 IgG or Fab induced little to no change in surface BLyS/BAFF expression (Fig. 5A). Heterotypic cross-linking of both Fc $\gamma$ RI and Fc $\gamma$ RIIa with antireceptor $\mathrm{mAbs}$ resulted in similar loss of surface BLyS/BAFF expression relative to crosslinking of $\mathrm{Fc} \gamma \mathrm{RI}$ alone. As a positive control for mAb IV.3 IgG and Fab activity, we tested the ability of cross-linked IV.3 and of 32.2 to elicit a rise in intracellular calcium levels. Homotypic ligation of either Fc $\gamma$ RI or Fc $\gamma$ RIIa was capable of inducing a calcium influx with Fc $\gamma$ RIIa generating a stronger response than Fc $\gamma$ RI (Fig. 5C). Heterotypic crosslinking of both Fc $\gamma \mathrm{RI}$ and Fc $\gamma$ RIIa enhanced the calcium influx to levels higher than Fc $\gamma \mathrm{RI}$ alone (Fig. 5D). Together, these results document a unique role for Fc $\gamma$ RI over Fc $\gamma$ RIIa in the induction of BLyS/BAFF release despite of the fact that both receptors utilize an ITAM motif and that $\mathrm{Fc} \gamma \mathrm{RIIa}$ resulted in a stronger $\mathrm{Ca}^{2+}$ influx than Fc $\gamma \mathrm{RI}$.

U937 cells and THP-1 cells also express the inhibitory Fc receptor, Fc $\gamma$ RIIb. Using the recently described anti-Fc $\gamma \mathrm{RIIb} \mathrm{mAb} 4 \mathrm{~F} 5 \mathrm{IgG}$ or $\mathrm{F}\left(\mathrm{ab}^{\prime}\right)_{2}$ (27), we cross-linked Fc $\gamma \mathrm{RIIb}$ alone or in combination with the anti-Fc $\gamma \mathrm{RI} \mathrm{mAb} 32.2 \mathrm{~F}\left(\mathrm{ab}^{\prime}\right)_{2}$. Homotypic cross-linking of Fc $\gamma$ RIIb did not result in any change in cell surface BLyS expression (Fig. 5A).

Surprisingly, though heterotypic cross-linking of Fc $\gamma \mathrm{RI}$ and Fc $\gamma \mathrm{RIIb}$ resulted in diminished rise of intracellular $\mathrm{Ca}^{2+}$ (Fig. 5D), there was no change in the magnitude of BLyS loss from the cell surface. These results suggest that BLyS cleavage is resistant to Fc $\gamma$ RIIb mediated inhibition.

To confirm the unique role of $\mathrm{Fc} \gamma \mathrm{RI}$ in inducing BLyS/BAFF shedding on primary myeloid cells, we performed the anti-receptor $\mathrm{mAb}$ cross-linking studies using peripheral blood monocytes. Rapid loss of BLyS/BAFF expression was observed after stimulation of the cells through Fc $\gamma$ RI. There was little reduction in BLyS/BAFF expression after stimulation of cell through Fc $\gamma$ RIIa (Fig. 5B). Consistent with the data in the U937 cell line, heterotypic ligation of Fc $\gamma$ RI with Fc $\gamma$ RIIa or Fc $\gamma$ RIIb showed little alteration of the level of Fc $\gamma$ RI induced BLyS/BAFF reduction (results not shown). 


\section{Biological activities of FcyR cross-linking derived BLyS}

The functional significance of Fc $\gamma$ receptor BLyS/BAFF shedding was determined by testing B cell viability as previously described (20) in co-cultures with either U937 cells or primary MNC. In these experiments, the U937 cells or MNC were cultured in wells in the presence or absence of pre-coated IgG and the isolated B cells were co-cultured in the same well separated by a $0.4 \mu \mathrm{m}$ transwell membrane. As previously shown (18), B cells cultured alone had poor survival with nearly $60 \%$ of cells non-viable after 3 days in culture while addition of soluble rBLyS maintained $100 \%$ cell viability (Fig. 6). In the absence of Fc $\gamma \mathrm{R}$ ligation, U937 cells and primary MNC increased B cell survival (Fig. $6 A \& B$ ), presumably due in part to constitutive BLyS shedding (see Fig. 4). However, with IgG stimulation, both U937 cells and MNC significantly enhanced B cell viability above levels observed in the absence of IgG stimulation ( $\mathrm{p}<0.002)$. Not only was viability maintained, the higher levels of BLyS/BAFF shedding from U937 cells resulted in a slight increase in B cell numbers suggesting proliferation. Enhanced B cell survival after U937 cell/MNC Fc $\gamma \mathrm{R}$ stimulation was reversed with the inclusion of the neutralizing anti-BLyS antibody 7D4 (Fc $\gamma \mathrm{R}$ stimulation $v s$ Fc $\gamma$ R stimulation plus 7D4 neutralization: p<0.018) (Fig. $6 A / B$ ). These results confirm that biologically active soluble BLyS/BAFF is released from monocytes by Fc $\gamma \mathrm{R}$ cross-linking.

\section{Discussion}

Our study reports for the first time that the shedding of soluble BLyS/BAFF from myeloid cells is regulated in an $\mathrm{Fc} \gamma$ receptor specific manner by opsonins of both innate and acquired immune origins. Both CRP and IgG triggered rapid and significant shedding of soluble BLyS/BAFF from the surface of myeloid cells. A unique role for Fc $\gamma$ RI (CD64) over Fc $\gamma$ RII is shown by direct anti-receptor mAb engagement. The shed BLyS/BAFF is biologically active and directly promotes B cell survival.

Of interest, our results show that Fc $\gamma \mathrm{RI}$ (CD64) is much more effective in IgG induced shedding process compared to Fc $\gamma$ RIIa (CD32A). Both Fc $\gamma$ RI and Fc $\gamma$ RIIa are ITAMbearing activating Fc $\gamma$ Rs, although the ITAM in the cytoplasmic domain of Fc $\gamma$ RIIa differs in primary sequence from the ITAM-containing common FcR $\gamma$-chains that associates with Fc $\gamma$ RI. There are now several lines of evidence suggesting that the ligand binding $a$-chain of Fc $\gamma$ RI can modulate FcR $\gamma$-chain associated receptor functions such as phagocytosis, regulation of Th2 cytokines production (IL-6 and IL-10), and antigen presentation (32-34). Receptor-induced shedding of BLyS/BAFF is not a property of all FcR $\gamma$-chain associated receptors because we observed no change in BLyS/BAFF expression after crosslinking of another $\gamma$-chain associated receptor CD89 (results not shown).

It is known that ITAM-dependent activation can be inhibited by concomitant ligation of ITIM bearing receptors such as Fc $\gamma$ RIIb $(35,36)$. However, when we cross-linked Fc $\gamma$ RI with Fc $\gamma \mathrm{RIIb}$, the level of membrane BLyS/BAFF expression was indistinguishable from ligation of $\mathrm{Fc} \gamma \mathrm{RI}$ alone despite significant reduction in the Fc $\gamma \mathrm{RI}$ induced $\mathrm{Ca}^{2+}$ flux. This result suggests that $\mathrm{Fc} \gamma \mathrm{R}$ mediated BLyS/BAFF shedding may be an ITAM-independent process (as shown in Fig. 4A). While we cannot exclude the possibility that myeloid cells do not express sufficient Fc $\gamma \mathrm{RIIb}$ to inhibit the cleavage signaling pathway, these levels of Fc $\gamma$ RIIb were sufficient to mediate over $70 \%$ inhibition of the Fc $\gamma$ RI triggered $\mathrm{Ca}^{2+}$ influx. Thus, either BLyS shedding is independent of ITAM signaling or it requires minimal levels of ITAM activation. Indeed, the tyrosine kinase inhibitor genistein achieved less than 50\% reduction of the $\operatorname{IgG}$ induced membrane BLyS/BAFF release (results not shown), suggesting that $\gamma$-chain tyrosine phosphorylation is not the only event contributing to BLyS/BAFF shedding. 
BLyS/BAFF is critical for maintaining homeostasis of primary B cells. Deficiency of BLyS in the mouse causes a block in B cell development, and blocking of the BLyS/APRIL receptor TACI can reverse the autoantibody mediated autoimmune phenotype in the NZB/ WF1 mouse $(9,37)$. Conversely, recent reports suggested that excess amount of BLyS can rescue self-reactive $\mathrm{B}$ cells from peripheral deletion and allow them to enter forbidden follicular and marginal zone niches (38) and over expression of BLyS/BAFF in the mouse causes autoimmune symptoms characteristic of SLE (39). It is likely that a furin-like protease plays a role in the cleavage of both cell surface BLyS/BAFF from myeloid cells and of intracellular BLyS/BAFF in neutrophils (16), but the exact enzyme or other factors that regulate proteolytic activity towards BLyS/BAFF remain unclear. Indeed, we observed that the furin inhibitor CMK and the metalloprotease inhibitor 1,10-phenanthroline demonstrated only marginal inhibition of $\mathrm{Fc} \gamma \mathrm{R}$ induced BLyS/BAFF shedding (results not shown). Interestingly, a similar protease-resistant Fc $\gamma \mathrm{RI}$ induced cleavage of CR1 (CD35) has been observed (40-42).

CRP circulates at a very low level in most healthy individuals, but in response to inflammation or infection, CRP levels rise rapidly and to a high level (43-45). CRP is traditionally regarded as an innate immune opsonin that acts in part through activation of the classical complement cascade and also interacts with myeloid receptors including Fc $\gamma \mathrm{R}$. Previous work indicates that CRP can induce secretion of IL-6 and matrix metalloproteinase 1 (MMP-1) (46), triggers shedding of L-selectin and upregulation of the $\beta 2$ integrin CD11b expression in myeloid cells (47), and triggers IL-6 receptor shedding from granulocytes (42). It is now recognized that many of these events are due to CRP engagement of Fc receptors on myeloid cells. Our observation raises the possibility that CRP could link innate responses to acquired immune responses by engaging $\mathrm{Fc} \gamma \mathrm{Rs}$ and modulating BLyS/BAFF cleavage resulting in promotion of B cell maturation.

Together, our studies demonstrate that the level of soluble functional BLyS/BAFF can be up-regulated by myeloid Fc $\gamma$ Rs, with a primary role for Fc $\gamma$ RI. A central role of Fc $\gamma$ RI allows for the regulation of soluble-cleaved BLyS/BAFF by both IgG and by the innate acute phase reactive CRP. Furthermore, a unique role for $\mathrm{Fc} \gamma \mathrm{RI}$ in regulation of antibody production is suggested through enhancement of antigen presentation (23) and through cleavage of membrane BLyS making soluble BLyS available for B cell activation. This role for myeloid Fc $\gamma$ RI contrasts with the ability of B cell Fc $\gamma$ RIIb to inhibit BCR signaling and antibody production. The production of an antibody/autoantibody promoting B cell survival factor by Fc $\gamma$ receptors provides a possible mechanism for known elevations in BLyS/BAFF in patients with autoantibody-associated autoimmune disease and supports current therapeutic BLyS/BAFF blockade in these diseases.

\section{References}

1. Mackay F, Browning JL. BAFF: a fundamental survival factor for B cells. Nat Rev Immunol. 2002; 2:465-475. [PubMed: 12094221]

2. Miller JP, Stadanlick JE, Cancro MP. Space, selection, and surveillance: setting boundaries with BLyS. J Immunol. 2006; 176:6405-6410. [PubMed: 16709796]

3. Woodland RT, Schmidt MR, Thompson CB. BLyS and B cell homeostasis. Semin Immunol. 2006; 18:318-326. [PubMed: 16931037]

4. Bossen C, Schneider P. BAFF, APRIL and their receptors: structure, function and signaling. Semin Immunol. 2006; 18:263-275. [PubMed: 16914324]

5. Salzer U, Jennings S, Grimbacher B. To switch or not to switch--the opposing roles of TACI in terminal B cell differentiation. Eur J Immunol. 2007; 37:17-20. [PubMed: 17171762] 
6. Do RK, Hatada E, Lee H, Tourigny MR, Hilbert D, Chen-Kiang S. Attenuation of apoptosis underlies B lymphocyte stimulator enhancement of humoral immune response. J Exp Med. 2000; 192:953-964. [PubMed: 11015437]

7. Batten M, Groom J, Cachero TG, Qian F, Schneider P, Tschopp J, Browning JL, Mackay F. BAFF mediates survival of peripheral immature B lymphocytes. J Exp Med. 2000; 192:1453-1466. [PubMed: 11085747]

8. Rolink AG, Tschopp J, Schneider P, Melchers F. BAFF is a survival and maturation factor for mouse B cells. Eur J Immunol. 2002; 32:2004-2010. [PubMed: 12115621]

9. Schiemann B, Gommerman JL, Vora K, Cachero TG, Shulga-Morskaya S, Dobles M, Frew E, Scott ML. An essential role for BAFF in the normal development of B cells through a BCMAindependent pathway. Science. 2001; 293:2111-2114. [PubMed: 11509691]

10. Jacob CO, Pricop L, Putterman C, Koss MN, Liu Y, Kollaros M, Bixler SA, Ambrose CM, Scott ML, Stohl W. Paucity of clinical disease despite serological autoimmunity and kidney pathology in lupus-prone New Zealand mixed 2328 mice deficient in BAFF. J Immunol. 2006; 177:26712680. [PubMed: 16888029]

11. Mackay F, Woodcock SA, Lawton P, Ambrose C, Baetscher M, Schneider P, Tschopp J, Browning JL. Mice transgenic for BAFF develop lymphocytic disorders along with autoimmune manifestations. J Exp Med. 1999; 190:1697-1710. [PubMed: 10587360]

12. Zhang J, Roschke V, Baker KP, Wang Z, Alarcon GS, Fessler BJ, Bastian H, Kimberly RP, Zhou T. Cutting edge: a role for B lymphocyte stimulator in systemic lupus erythematosus. J Immunol. 2001; 166:6-10. [PubMed: 11123269]

13. Mariette X, Roux S, Zhang J, Bengoufa D, Lavie F, Zhou T, Kimberly R. The level of BLyS (BAFF) correlates with the titre of autoantibodies in human Sjogren's syndrome. Ann Rheum Dis. 2003; 62:168-171. [PubMed: 12525388]

14. Groom J, Kalled SL, Cutler AH, Olson C, Woodcock SA, Schneider P, Tschopp J, Cachero TG, Batten M, Wheway J, Mauri D, Cavill D, Gordon TP, Mackay CR, Mackay F. Association of BAFF/BLyS overexpression and altered B cell differentiation with Sjogren's syndrome. J Clin Invest. 2002; 109:59-68. [PubMed: 11781351]

15. Nardelli B, Belvedere O, Roschke V, Moore PA, Olsen HS, Migone TS, Sosnovtseva S, Carrell JA, Feng P, Giri JG, Hilbert DM. Synthesis and release of B-lymphocyte stimulator from myeloid cells. Blood. 2001; 97:198-204. [PubMed: 11133761]

16. Scapini P, Nardelli B, Nadali G, Calzetti F, Pizzolo G, Montecucco C, Cassatella MA. G-CSFstimulated neutrophils are a prominent source of functional BLyS. J Exp Med. 2003; 197:297-302. [PubMed: 12566413]

17. Gorelik L, Gilbride K, Dobles M, Kalled SL, Zandman D, Scott ML. Normal B cell homeostasis requires B cell activation factor production by radiation-resistant cells. J Exp Med. 2003; 198:937945. [PubMed: 12975458]

18. Ohata J, Zvaifler NJ, Nishio M, Boyle DL, Kalled SL, Carson DA, Kipps TJ. Fibroblast-like synoviocytes of mesenchymal origin express functional B cell-activating factor of the TNF family in response to proinflammatory cytokines. J Immunol. 2005; 174:864-870. [PubMed: 15634908]

19. Krumbholz M, Theil D, Derfuss T, Rosenwald A, Schrader F, Monoranu CM, Kalled SL, Hess DM, Serafini B, Aloisi F, Wekerle H, Hohlfeld R, Meinl E. BAFF is produced by astrocytes and up-regulated in multiple sclerosis lesions and primary central nervous system lymphoma. J Exp Med. 2005; 201:195-200. [PubMed: 15642740]

20. Craxton A, Magaletti D, Ryan EJ, Clark EA. Macrophage- and dendritic cell--dependent regulation of human B-cell proliferation requires the TNF family ligand BAFF. Blood. 2003; 101:44644471. [PubMed: 12531790]

21. Schneider P, MacKay F, Steiner V, Hofmann K, Bodmer JL, Holler N, Ambrose C, Lawton P, Bixler S, Acha-Orbea H, Valmori D, Romero P, Werner-Favre C, Zubler RH, Browning JL, Tschopp J. BAFF, a novel ligand of the tumor necrosis factor family, stimulates B cell growth. J Exp Med. 1999; 189:1747-1756. [PubMed: 10359578]

22. Gosselin EJ, Wardwell K, Gosselin DR, Alter N, Fisher JL, Guyre PM. Enhanced antigen presentation using human $\mathrm{Fc}$ gamma receptor (monocyte/macrophage)-specific immunogens. $\mathrm{J}$ Immunol. 1992; 149:3477-3481. [PubMed: 1431118] 
23. Heijnen IA, van Vugt MJ, Fanger NA, Graziano RF, de Wit TP, Hofhuis FM, Guyre PM, Capel PJ, Verbeek JS, van de Winkel JG. Antigen targeting to myeloid-specific human Fc gamma RI/CD64 triggers enhanced antibody responses in transgenic mice. J Clin Invest. 1996; 97:331-338. [PubMed: 8567952]

24. Li X, Wu J, Carter RH, Edberg JC, Su K, Cooper GS, Kimberly RP. A novel polymorphism in the Fcgamma receptor IIB (CD32B) transmembrane region alters receptor signaling. Arthritis Rheum. 2003; 48:3242-3252. [PubMed: 14613290]

25. Liu W, Szalai A, Zhao L, Liu D, Martin F, Kimberly RP, Zhou T, Carter RH. Control of spontaneous B lymphocyte autoimmunity with adenovirus-encoded soluble TACI. Arthritis Rheum. 2004; 50:1884-1896. [PubMed: 15188365]

26. Kilpatrick JM, Kearney JF, Volanakis JE. Demonstration of calcium-induced conformational change(s) in C-reactive protein by using monoclonal antibodies. Mol Immunol. 1982; 19:11591165. [PubMed: 6183579]

27. Su K, Yang H, Li X, Li X, Gibson AW, Cafardi JM, Zhou T, Edberg JC, Kimberly RP. Expression Profile of Fc $\{$ gamma\}RIIb on Leukocytes and Its Dysregulation in Systemic Lupus Erythematosus. J Immunol. 2007; 178:3272-3280. [PubMed: 17312177]

28. Volanakis JE, Clements WL, Schrohenloher RE. C-reactive protein: purification by affinity chromatography and physicochemical characterization. J Immunol Methods. 1978; 23:285-295.

29. Wu J, Edberg JC, Redecha PB, Bansal V, Guyre PM, Coleman K, Salmon JE, Kimberly RP. A novel polymorphism of FcgammaRIIIa (CD16) alters receptor function and predisposes to autoimmune disease. J Clin Invest. 1997; 100:1059-1070. [PubMed: 9276722]

30. Du Clos TW, Mold C. C-reactive protein: an activator of innate immunity and a modulator of adaptive immunity. Immunol Res. 2004; 30:261-277. [PubMed: 15531769]

31. Moore PA, Belvedere O, Orr A, Pieri K, LaFleur DW, Feng P, Soppet D, Charters M, Gentz R, Parmelee D, Li Y, Galperina O, Giri J, Roschke V, Nardelli B, Carrell J, Sosnovtseva S, Greenfield W, Ruben SM, Olsen HS, Fikes J, Hilbert DM. BLyS: member of the tumor necrosis factor family and B lymphocyte stimulator. Science. 1999; 285:260-263. [PubMed: 10398604]

32. Edberg JC, Qin H, Gibson AW, Yee AM, Redecha PB, Indik ZK, Schreiber AD, Kimberly RP. The CY domain of the Fcgamma RIa alpha-chain (CD64) alters gamma-chain tyrosine-based signaling and phagocytosis. J Biol Chem. 2002; 277:41287-41293. [PubMed: 12200451]

33. Kurosaka K, Watanabe N, Kobayashi Y. Potentiation by human serum of anti-inflammatory cytokine production by human macrophages in response to apoptotic cells. J Leukoc Biol. 2002; 71:950-956. [PubMed: 12050179]

34. van Vugt MJ, Kleijmeer MJ, Keler T, Zeelenberg I, van Dijk MA, Leusen JH, Geuze HJ, van de Winkel JG. The FcgammaRIa (CD64) ligand binding chain triggers major histocompatibility complex class II antigen presentation independently of its associated FcR gamma-chain. Blood. 1999; 94:808-817. [PubMed: 10397749]

35. Amigorena S, Bonnerot C, Drake JR, Choquet D, Hunziker W, Guillet JG, Webster P, Sautes C, Mellman I, Fridman WH. Cytoplasmic domain heterogeneity and functions of IgG Fc receptors in B lymphocytes. Science. 1992; 256:1808-1812. [PubMed: 1535455]

36. Muta T, Kurosaki T, Misulovin Z, Sanchez M, Nussenzweig MC, Ravetch JV. A 13-amino-acid motif in the cytoplasmic domain of Fc gamma RIIB modulates B-cell receptor signalling. Nature. 1994; 368:70-73. [PubMed: 8107887]

37. Gross JA, Dillon SR, Mudri S, Johnston J, Littau A, Roque R, Rixon M, Schou O, Foley KP, Haugen H, McMillen S, Waggie K, Schreckhise RW, Shoemaker K, Vu T, Moore M, Grossman A, Clegg CH. TACI-Ig neutralizes molecules critical for B cell development and autoimmune disease. impaired B cell maturation in mice lacking BLyS. Immunity. 2001; 15:289-302. [PubMed: 11520463]

38. Thien M, Phan TG, Gardam S, Amesbury M, Basten A, Mackay F, Brink R. Excess BAFF rescues self-reactive B cells from peripheral deletion and allows them to enter forbidden follicular and marginal zone niches. Immunity. 2004; 20:785-798. [PubMed: 15189742]

39. Gross JA, Johnston J, Mudri S, Enselman R, Dillon SR, Madden K, Xu W, Parrish-Novak J, Foster D, Lofton-Day C, Moore M, Littau A, Grossman A, Haugen H, Foley K, Blumberg H, Harrison K, 
Kindsvogel W, Clegg CH. TACI and BCMA are receptors for a TNF homologue implicated in Bcell autoimmune disease. Nature. 2000; 404:995-999. [PubMed: 10801128]

40. Kuhn SE, Nardin A, Klebba PE, Taylor RP. Escherichia coli bound to the primate erythrocyte complement receptor via bispecific monoclonal antibodies are transferred to and phagocytosed by human monocytes in an in vitro model. J Immunol. 1998; 160:5088-5097. [PubMed: 9590260]

41. Craig ML, Bankovich AJ, McElhenny JL, Taylor RP. Clearance of anti-double-stranded DNA antibodies: the natural immune complex clearance mechanism. Arthritis Rheum. 2000; 43:22652275. [PubMed: 11037886]

42. Pepys MB. C-reactive protein fifty years on. Lancet. 1981; 1:653-657. [PubMed: 6110874]

43. Jones SA, Novick D, Horiuchi S, Yamamoto N, Szalai AJ, Fuller GM. C-reactive protein: a physiological activator of interleukin 6 receptor shedding. J Exp Med. 1999; 189:599-604. [PubMed: 9927522]

44. Zouki C, Beauchamp M, Baron C, Filep JG. Prevention of In vitro neutrophil adhesion to endothelial cells through shedding of L-selectin by C-reactive protein and peptides derived from C-reactive protein. J Clin Invest. 1997; 100:522-529. [PubMed: 9239398]

45. Williams TN, Zhang CX, Game BA, He L, Huang Y. C-reactive protein stimulates MMP-1 expression in U937 histiocytes through Fc[gamma]RII and extracellular signal-regulated kinase pathway: an implication of CRP involvement in plaque destabilization. Arterioscler Thromb Vasc Biol. 2004; 24:61-66. [PubMed: 14592848]

46. Woollard KJ, Fisch C, Newby R, Griffiths HR. C-reactive protein mediates CD11b expression in monocytes through the non-receptor tyrosine kinase, Syk, and calcium mobilization but not through cytosolic peroxides. Inflamm Res. 2005; 54:485-492. [PubMed: 16389569]

47. Takai T. Fc receptors and their role in immune regulation and autoimmunity. J Clin Immunol. 2005; 25:1-18. [PubMed: 15742153] 
A
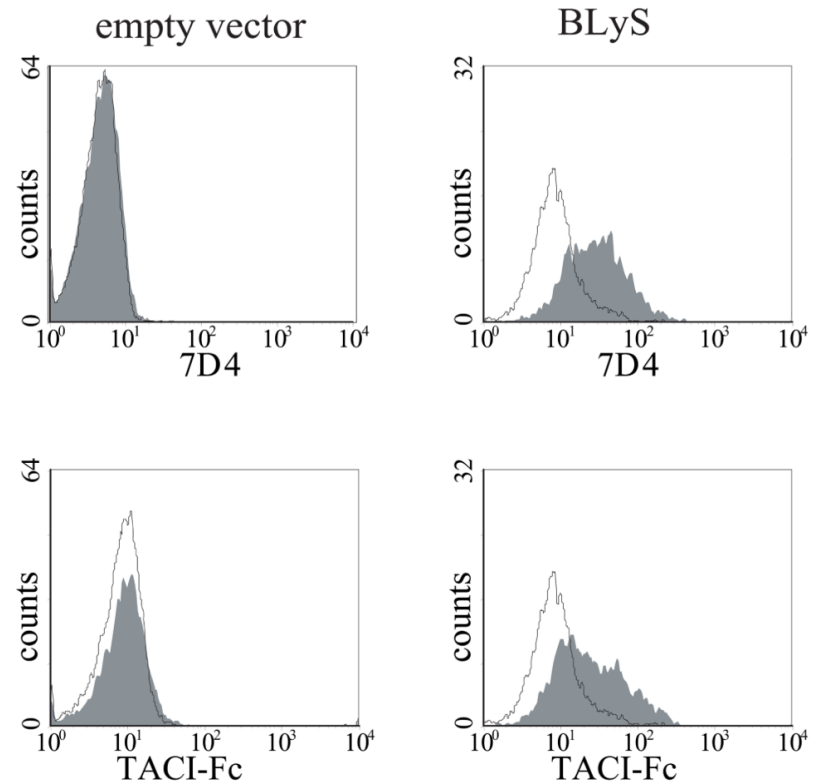

$\mathrm{B}$

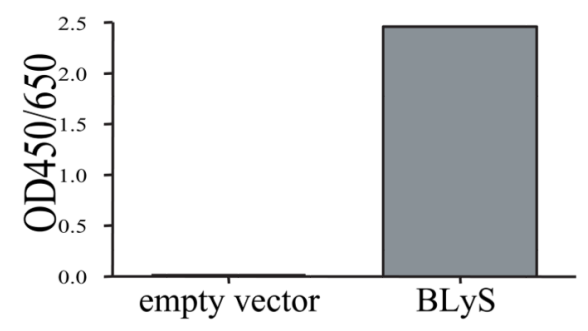

Figure 1. Characterization of the anti-BLyS antibody 7D4

(A) Flow cytometry analysis of $293 \mathrm{~T}$ cells transfected with human BLyS or empty vector. Cells were stained with $10 \mu \mathrm{g} / \mathrm{ml}$ TACI-Fc fusion protein followed by PE-conjugated antihuman IgG (lower panel) or $5 \mu \mathrm{g} / \mathrm{ml} 7 \mathrm{D} 4$ followed by PE-conjugated anti-mouse IgG2b (upper panel). (B) Expression levels of BLyS in culture supernatants of $293 \mathrm{~T}$ cells $\left(5 \times 10^{5}\right.$ / $\mathrm{ml}$ ) cultured in fresh medium for 24 hours. Soluble BLyS in culture supernatants was measured by sandwich ELISA using mAb 7D4 as capture antibody and rabbit anti-human BLyS polyclonal antibody as the detection antibody. 
A

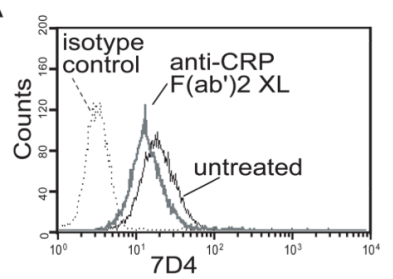

$\mathrm{C}_{8}$

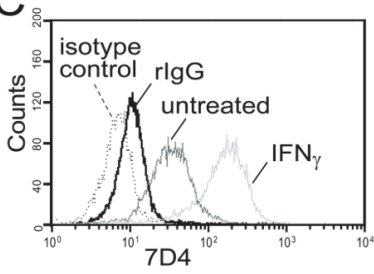

E

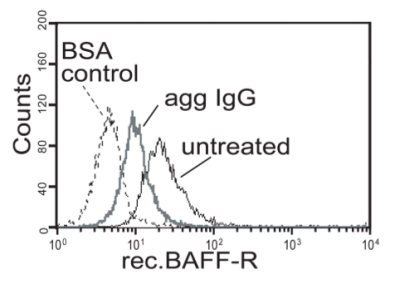

B

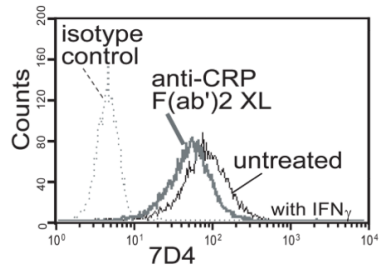

$\mathrm{D}$

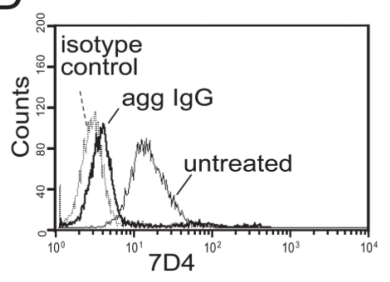

$\mathrm{F}$

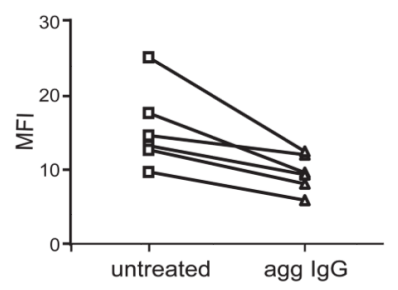

Figure 2. CRP and IgG induced reduction in membrane BLyS (mBLyS) expression U937 cells (A), or U937 cells pretreated with IFN $\gamma$ overnight (B), were incubated with CRP $(10 \mu \mathrm{g} / \mathrm{ml})$ and then stimulated with anti-CRP F $\left(\mathrm{ab}^{\prime}\right)_{2}$ mAb HD2-4 $(10 \mu \mathrm{g} / \mathrm{ml})$ followed by crosslinking with $\mathrm{GaM} \mathrm{F}(\mathrm{ab})^{\prime}{ }_{2}(35 \mu \mathrm{g} / \mathrm{ml})$, and surface BLyS expression was measured with mAb 7D4. (C\&D) U937 cells were incubated overnight alone or in the presence of rabbit IgG (rIgG) $(200 \mathrm{mg} / \mathrm{ml}$ pre-coated on the plate surface), IFN $\gamma(200 \mathrm{U} / \mathrm{ml})$, or aggregated human $\mathrm{IgG}(\mathrm{agg} \operatorname{IgG})(200 \mathrm{ug} / \mathrm{ml})$ as indicated, and cells were stained for surface mBLyS expression. Data presented are representative of three or more independent experiments. (E) U937 cells were incubated 30 mins alone or in the presence of agg IgG, followed by determination of surface mBLyS expression by Alexa 488 conjugated BAFF-R recombinant protein. Alexa488 conjugated BSA was used as background staining control. (F) Human PBMC were incubated with or without aggregated human IgG for $30 \mathrm{~min}$, followed by determination of surface mBLyS expression on $\mathrm{CD}_{1} 4^{+}$cells by flow cytometry. Stimulated versus control, $p=0.012, \mathrm{n}=6$. 

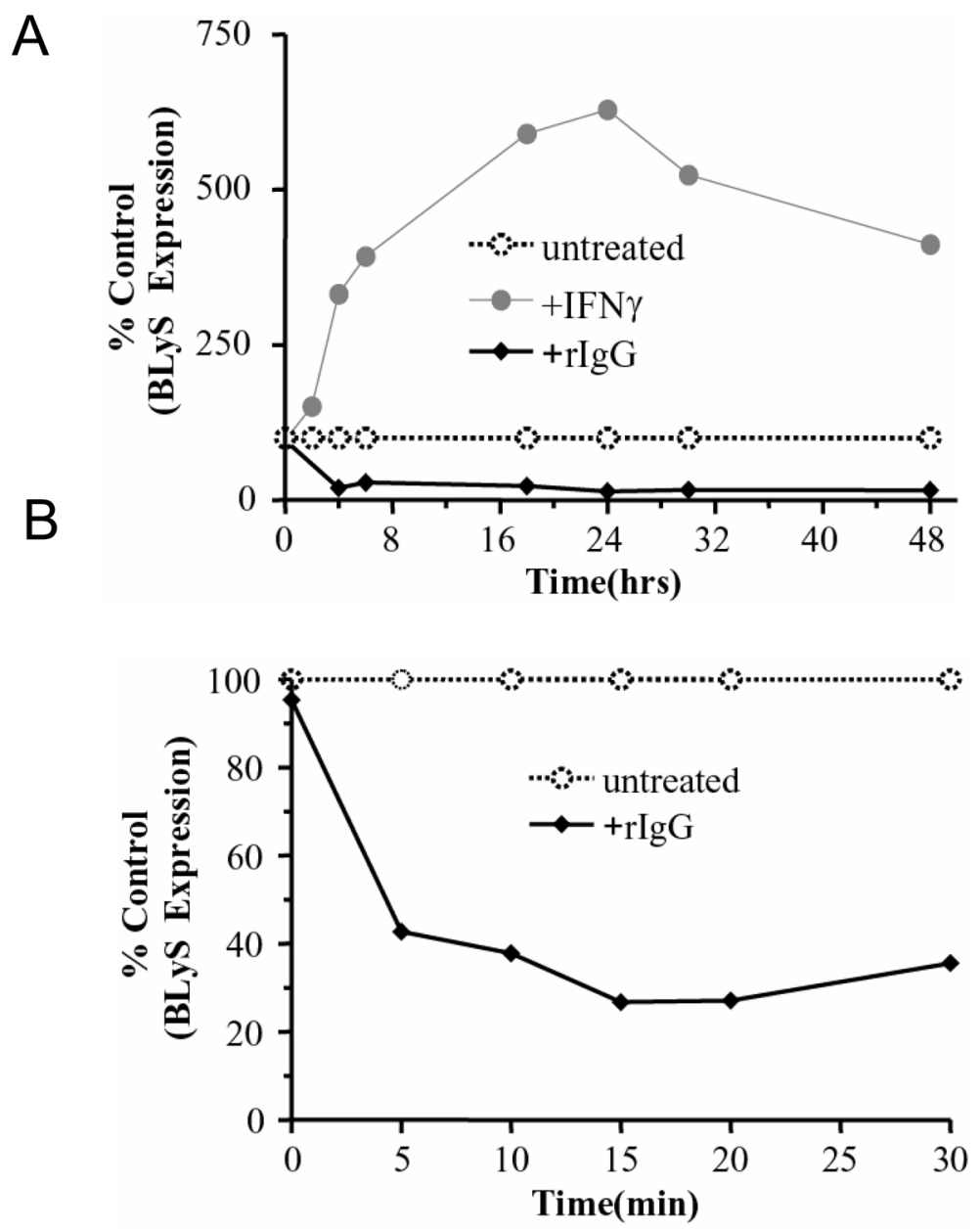

Figure 3. Kinetic analysis of mBLyS expression

U937 cells were incubated in the presence or absence of plate-bounded $\mathrm{rgG}(200 \mathrm{mg} / \mathrm{ml}$ precoated on the plate surface) or IFN $\gamma(200 \mathrm{U} / \mathrm{ml})$ for varying times, followed by determination of surface mBLyS expression by flow cytometry. Data are presented relative to control mBLyS expression versus stimulated cells. 3 to 5 independent time course studies were performed. 
A

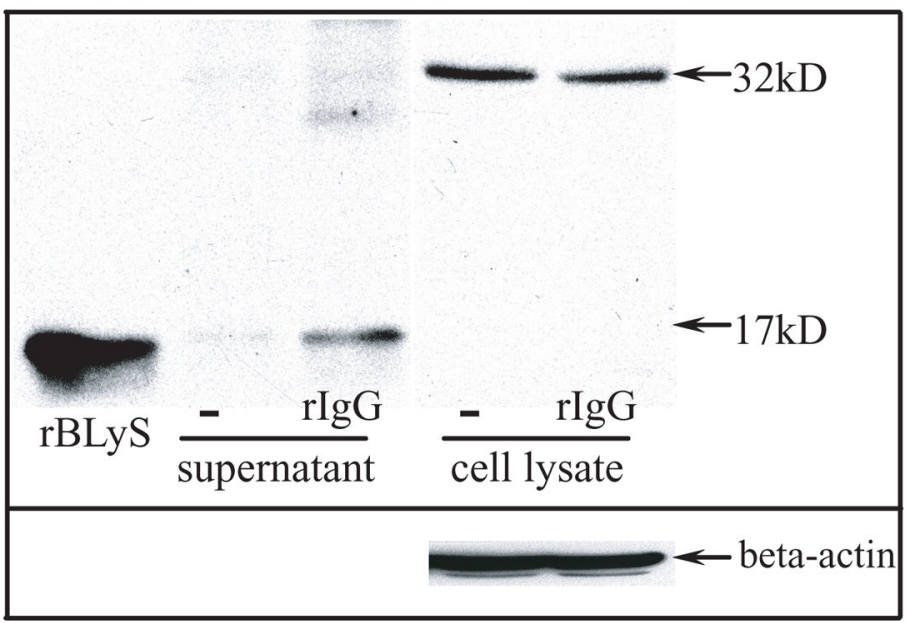

B

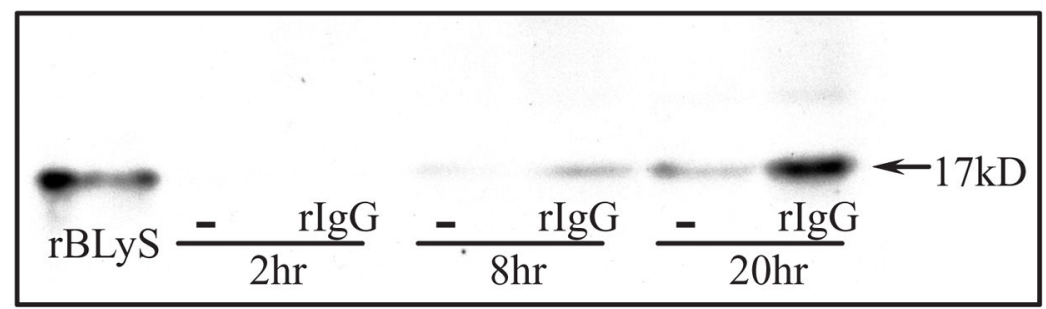

Figure 4. Soluble BLyS released into supernatants upon Fc $\gamma \mathrm{R}$ cross-linking Culture supernatants of THP-1 cells (A) or U937 cells (B) at varying time points were analyzed by immunoprecipitation of soluble BLyS. Cells were incubated with or without plate-bound rIgG for 24hrs (A) or for 3 different time points (B). BLyS was immunoprecipitated from culture supernatants $(\mathbf{A} \& \mathbf{B})$ and whole cell lysates (A) with antiBLyS mAb 7D4 bound to protein G-agarose. The membrane $32 \mathrm{kD}$ and cleaved soluble $17 \mathrm{kD}$ forms of BLyS are indicated. Recombinant BLyS (extra cellular domain) is also shown. As a loading control, the membrane in (A) was stripped and reprobed with an antiactin antibody. Data are one representative experiment of three independent experiments. 

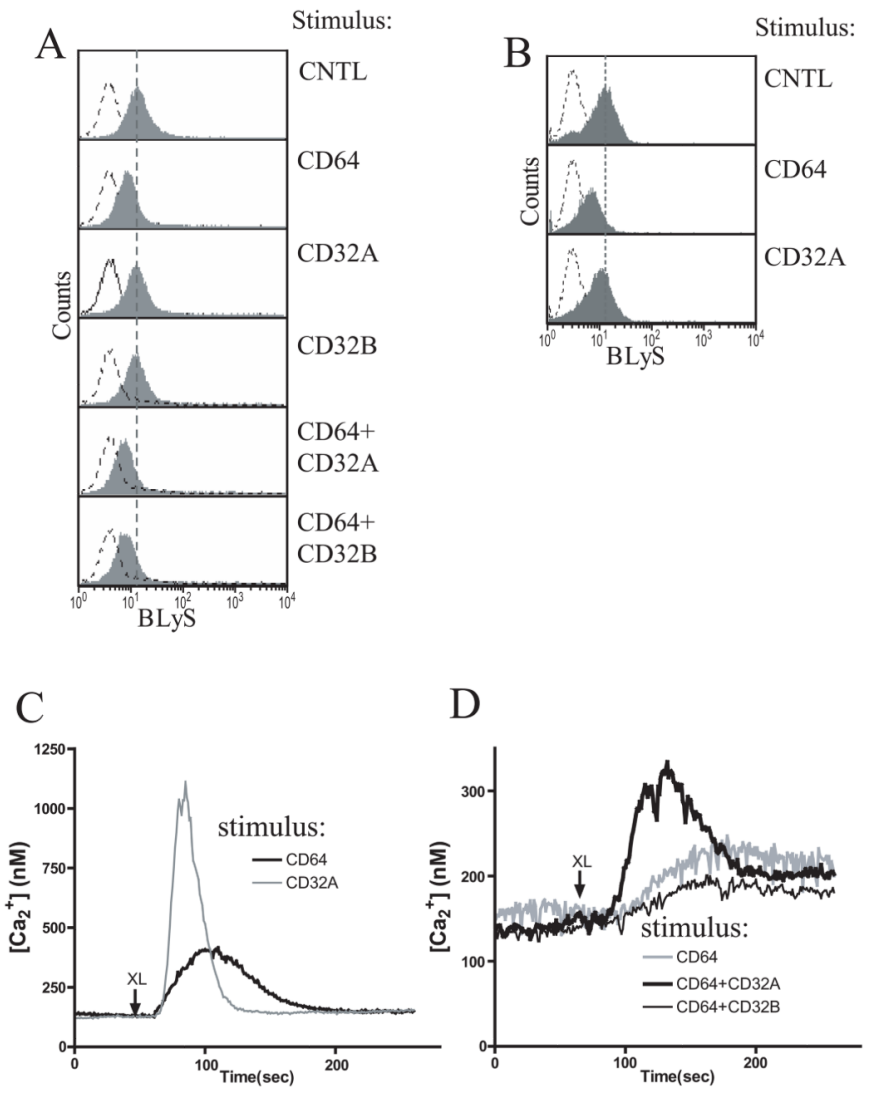

Figure 5. Fc $\gamma \mathrm{RI}$ is the major inducer of BLyS release from U937 cells (A) U937 cells $\left(5 \times 10^{6} / \mathrm{ml}\right)$ were stimulated by receptor specific cross-linking of Fc $\gamma \mathrm{Rs}$. Fc $\gamma$ Rs were cross-linked using anti-Fc $\gamma$ RI mAb $32.2(10 \mu \mathrm{g} / \mathrm{ml})$, anti-Fc $\gamma$ RIIa mAb IV3 $(10 \mu \mathrm{g} / \mathrm{ml})$ and/or anti-Fc $\gamma$ RIIb mAb 4F5 $(10 \mu \mathrm{g} / \mathrm{ml})$ followed by GaM F(ab') ${ }_{2}$. (B) PBMC were stimulated with anti-Fc $\gamma$ RI mAb32.2 F(ab') $)_{2}$ or anti-Fc $\gamma$ RIIa mAb IV3 Fab followed by $\mathrm{GaM} \mathrm{F}\left(\mathrm{ab}^{\prime}\right)_{2}$. CD14 positive cells were analyzed for mBLyS expression by flow cytometry. (C) Homotypic crosslinking of $32.2 \mathrm{IgG}$ or IV3 IgG induced a transient rise in intracellular $\mathrm{Ca}^{2+}$ in U937 cells. (D) Calcium influx induced by heterotypic ligation of 32.2 $\mathrm{F}\left(\mathrm{ab}^{\prime}\right)_{2}$ (CD64) and either IV3 Fab (CD32A) or 4F5 Fab (CD32B) compared with $32.2 \mathrm{~F}(\mathrm{ab}$ $\left.{ }^{\prime}\right)_{2}$ alone in U937 cells. Data presented are representative of 3 independent experiments. 
A

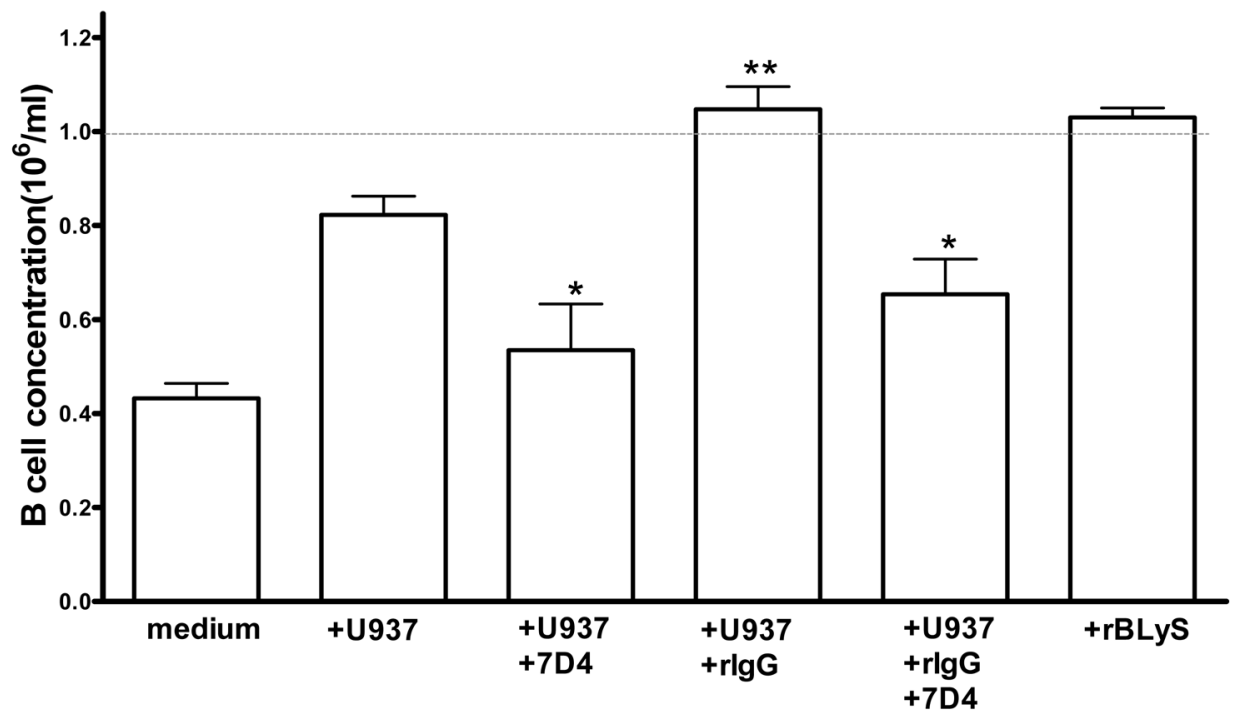

B

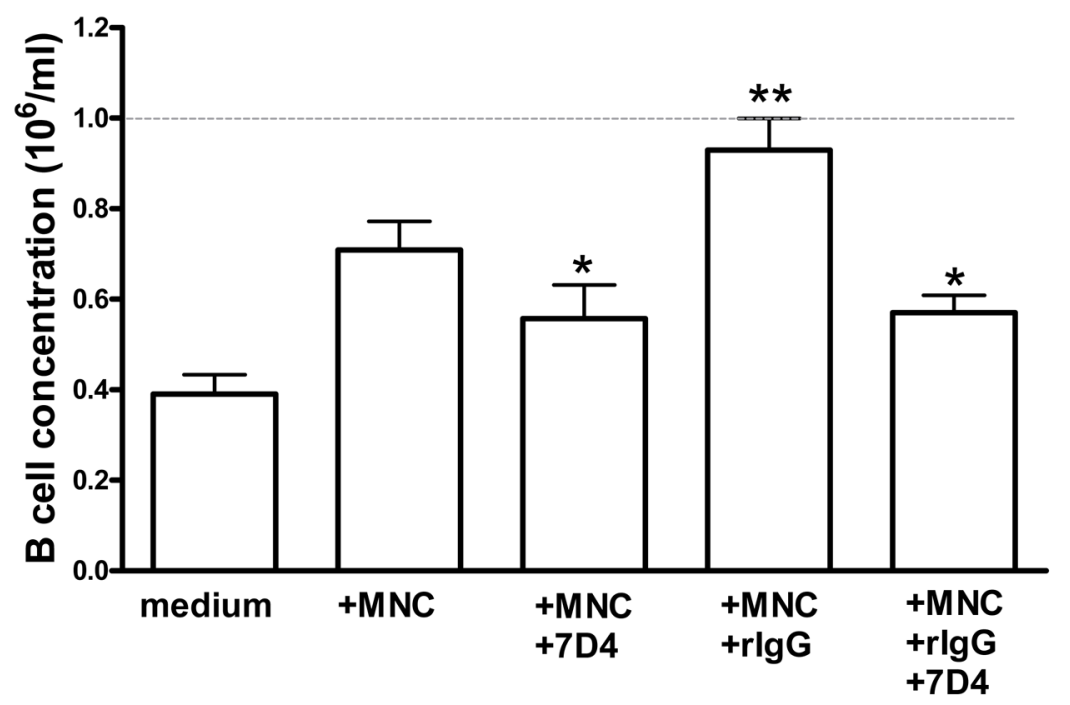

Figure 6. Released soluble BLyS by Fc $\gamma R$ stimulation supports $B$ cell survival in vitro Freshly isolated CD $19^{+} \mathrm{B}$ cells from healthy adults were cultured in the upper chamber of a transwell chamber. The bottom chamber contained either medium alone, U937 cells ( \pm rIgG) (A) or primary CD19 depleted MNC ( \pm rIgG) (B) for $72 \mathrm{hrs}$. Trypan blue negative B cells were determined. As a positive control, recombinant soluble BLyS $(200 \mathrm{ng} / \mathrm{ml})$ was used (A). BLyS activity was neutralized with a blocking antibody (mAb 7D4, 50 $\mu \mathrm{g} / \mathrm{ml})$ (A\&B). (A) $n=3-10$ independent determinations; (B) $n=4-7$ independent determinations. * $\mathrm{p}<0.018, * * \mathrm{p}<0.002$. 